\title{
Correction of Poland's Syndrome: Case Report and Review of the Current Literature
}

\author{
Tilmann Lantzsch $^{\mathrm{a}} \quad$ Dieter Lampe $^{\mathrm{b}} \quad$ Eva J. Kantelhardt ${ }^{\mathrm{c}}$ \\ ${ }^{a}$ Klinik für Gynäkologie, Krankenhaus St. Elisabeth und St. Barbara Halle, ${ }^{b}$ Klinik für Gynäkologie und Geburtshilfe, Asklepios Klinik \\ Weißenfels-Hohenmölsen, 'Universitätsklinik und Poliklinik für Frauenheilkunde, Martin-Luther-Universität Halle-Wittenberg, Germany
}

\section{Keywords}

Poland's syndrome · Breast hypoplasia ·

Breast reconstruction - Malformation

\section{Summary}

Background: Poland's syndrome, a rare congenital anomaly, consists of unilateral absence of the pectoralis major muscle, ipsilateral brachysyndactyly, and occasionally associated other malformations of the anterior chest wall, mamilla, and mamma. Case Report: In the case of a 32-yearold woman, marked hypoplasia of the right breast and the right nipple, malformation of the right upper limb with brachysyndactyly and microdactyly were noted, all present since birth. This paper describes the surgical technique and possible complications of reconstruction of the chest wall deformity with a solid silicone implant and a latissimus dorsi flap. The current literature on the topic is reviewed. Conclusion: The surgical method with autologous material and implants is a sufficient technique for chest wall reconstruction and gives a good long-term result in case of Poland's syndrome.

\section{Introduction}

Poland's syndrome was initially reported by Sir Alfred Poland in 1841 as an absence of the pectoralis major and minor muscles and malformation of the ipsilateral upper limb [1]. Poland's syndrome is also described as Poland's syndactyly or 'Amazone syndrome'. Other authors characterized the syndrome by congenital aplasia or hypoplasia of the sternocostal head of the pectoralis major muscle, associated with ipsilateral malformation of the breast, nipple, and the upper limb. The incidence has been estimated between 1:30,000 and $1: 80,000$ of live births, with a gender predominance in men at a

\section{KARGER}

Fax +497614520714

Information@Karger.com

www.karger.com

\section{(c) 2013 S. Karger GmbH, Freiburg}

$1661-3791 / 13 / 0082-0139 \$ 38.00 / 0$

Accessible online at:

www.karger.com/brc

\author{
Schlüsselwörter \\ Poland-Syndrom · Brusthypoplasie . \\ Brustrekonstruktion - Malformation
}

\section{Zusammenfassung}

Hintergrund: Das Poland-Syndrom, eine seltene kongenitale Anomalie, ist durch eine einseitige Fehlbildung des Mamillen-Areola-Komplexes und der Mamma sowie des Musculus pectoralis major, eine ipsilaterale Brachysyndaktylie und gelegentliche Fehlbildung der Brustwand gekennzeichnet. Fallbericht: Bei einer 32-jährigen Frau wurde eine ausgeprägte Hypoplasie der rechten Mamma und des MamillenAreola-Komplexes sowie eine Fehlbildung des rechten Armes mit Brachysyndaktylie und Mikrodaktylie festgestellt, die alle seit ihrer Geburt vorlagen. Dieser Artikel beschreibt die operative Therapie und die möglichen Komplikationen, die bei der Korrektur mittels einer Latissimus-dorsi-Lappenplastik und einer Implantateinlage auftreten können. Eine Zusammenfassung der aktuellen Literatur wird geboten. Schlussfolgerung: Die Methode der autologen Mammarekonstruktion mit Implantateinlage ist eine zuverlässige Methode zur Brustrekonstruktion bei Patientinnen mit Poland-Syndrom und ist mit einem guten Langzeitergebnis verbunden.

ratio of 3:1 [2]. At present, approximately 400 cases of Poland's syndrome have been reported.The literature describes abnormalities associated with the syndrome, including aplasia or hypoplasia of the rib cage, vertebral defects, and dextrocardia as common findings. In 4 cases of the literature, kidney abnormalities associated with the syndrome have been reported [3].

The cause of Poland's syndrome is unknown. However, interruption of the early embryonic blood supply in the subclavian arteries, the vertebral arteries, and/or other branches has been hypothesized. Most reported cases are sporadic, but the disease may be inherited as an autosomal-dominant trait. The responsible gene has not yet been mapped [4]. 


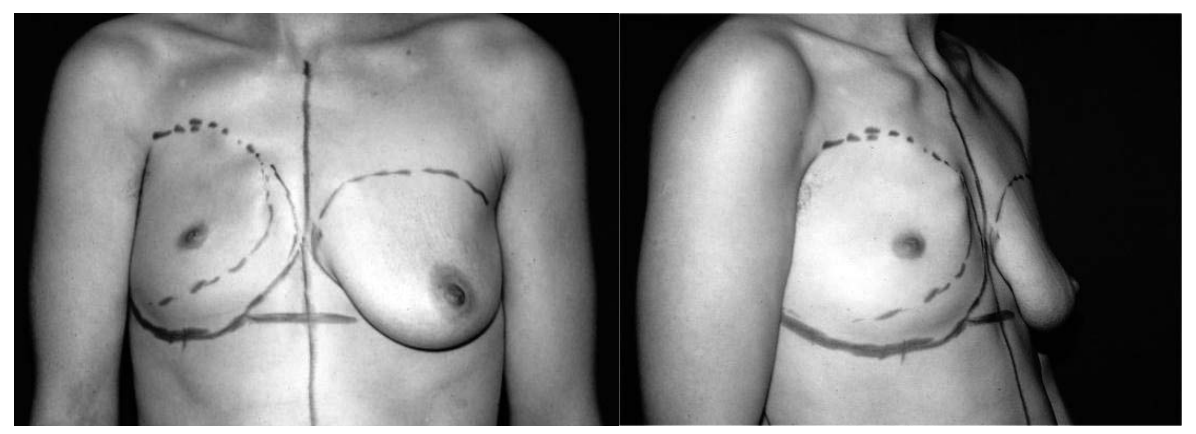

Fig. 1. Poland's syndrome preoperatively.

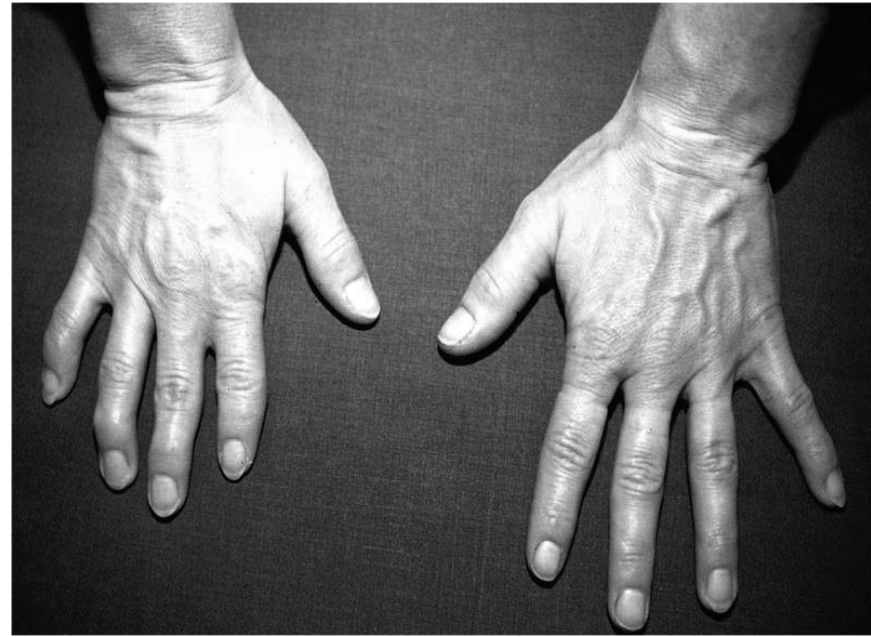

Fig. 2. Brachysyndactyly in Poland's syndrome.

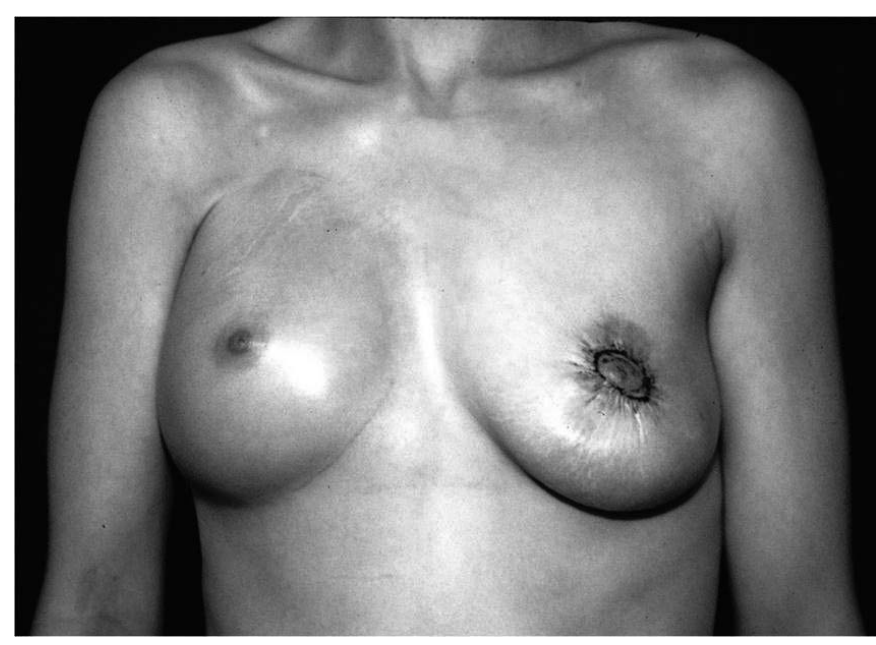

Fig. 4. Poland's syndrome postoperatively.

Several articles have reported on different kinds of neoplasms in Poland's syndrome patients and the association with an increased incidence of malignancy, such as leiomyosarcoma, neuroblastoma, leukemia, and Wilms' tumor. Summarizing 400 described cases of the syndrome, an increased risk of malignancy of the breast in this group of patients may be possible [5]. 5 cases of breast cancer have

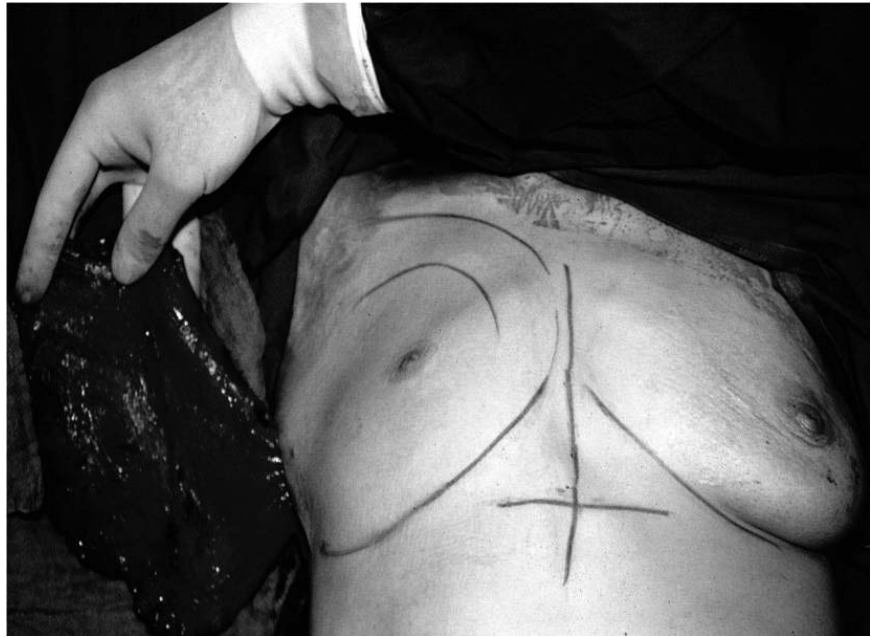

Fig. 3. Intraoperative muscle flap to correct the chest wall defect in Poland's syndrome.

been reported previously $[6,7]$. The hypoplastic breast should be monitored similarly to the normal breast. There is no difference in diagnostics or therapy for breast cancer in these patients.

\section{Case Report}

A 32-year-old woman presented at the University of Halle, Germany, as an outpatient asking for reconstruction of her hypoplastic breast. She was born with Poland's syndrome, presenting with hypoplasia of the right breast and the nipple-areola complex and absence of the pectoralis major muscle (fig. 1). The ipsilateral upper limb showed brachysyndactyly (fig. 2). Ultrasound of the abdomen showed a normally configured urogenital tract. Size and position of both kidneys were correct. There was no sign of dextrocardia, hypoplasia of the forearm, thoracic cage defects, or herniation of the lung. She was within normal limits in height, weight, and intelligence.

Reconstruction was performed under general anesthesia with a skinfree latissimus dorsi flap (LD flap) and placement of a 215 -ccm silicone implant. The incision was marked preoperatively for optimal positioning of the flap. The initial procedure was combined with contralateral mastopexy for symmetry (fig. 3). The flap was initially denerved to exclude contractions of the reconstructed breast. A small suction drain was placed alongside the implant.

The patient had an uneventful postoperative course (fig. 4). Postoperatively she obtained a symmetric result. The patient was lost to long-term follow-up. 


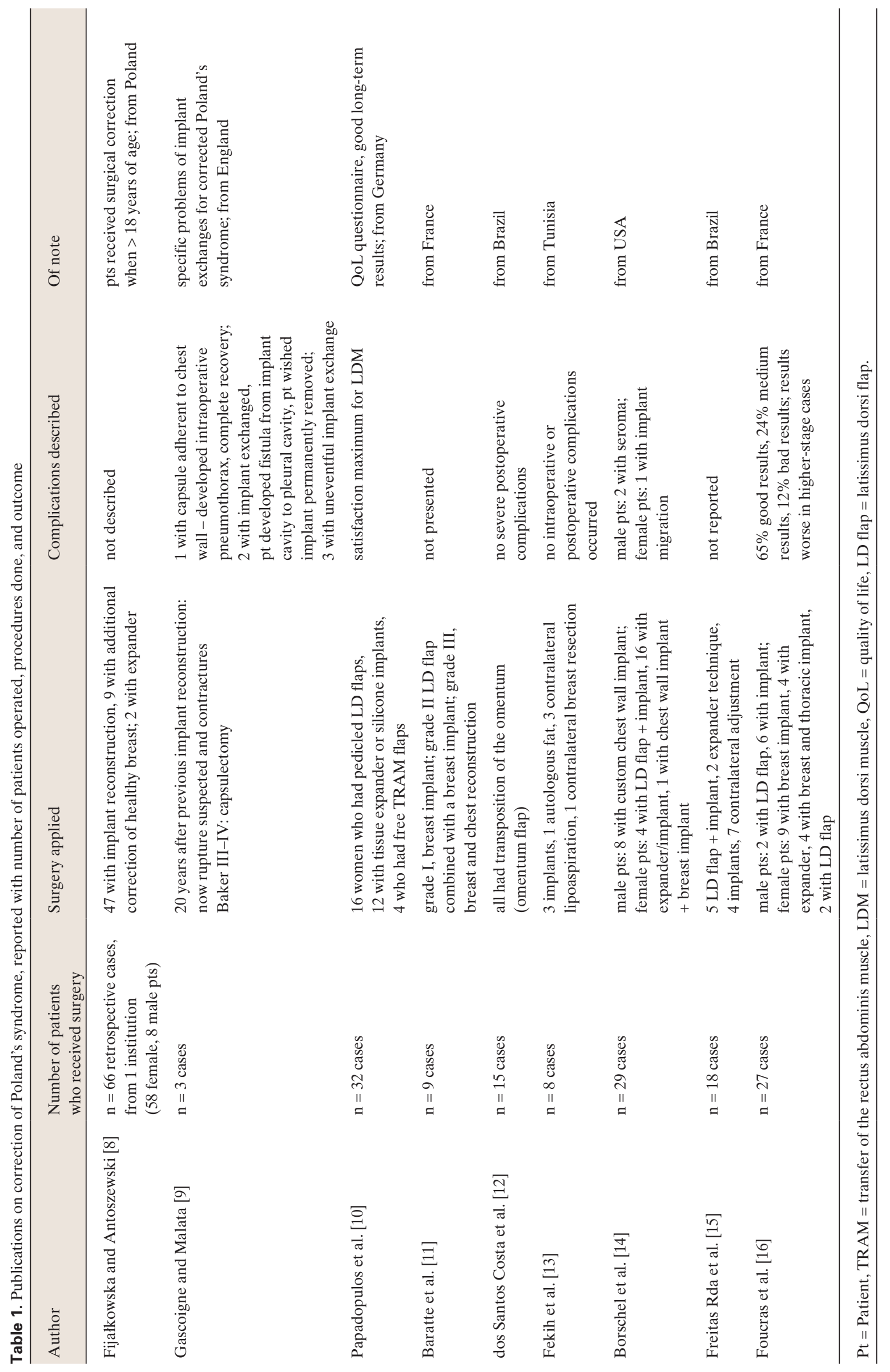




\section{Review of the Literature}

The PubMed database was screened for relevant articles within the last 10 years on 'Poland syndrome breast', reviewing publications that describe surgical procedures. Articles mentioning $\geq 3$ cases are presented in table 1 .

The type of surgery used depends highly on the extent of the malformation and individual patient preferences (e.g. choice about sole implants vs. LD flap). Newly described methods include omentum flap techniques.

Complications described in the literature are few and do not differ from complications seen in the respective procedures done for other reasons. Due to aplasia of muscular and fatty structures as well as rigid skin, contractures after implant insertion may be more frequent and should be treated with caution (beware of nearby pleura). Due to the congenital nature of the abnormality, patients may be treated early in life. Therefore, a future change in the figure of the patient has to be anticipated.

\section{Conclusion}

Our patient shows characteristic findings of Poland's syndrome including the absence of the right pectoralis major muscle and ipsilateral hand deformities.

Reconstruction of the chest wall in patients with Poland's syndrome may lead to intra- or postoperative complications [17]. If the skin cover of an implant is not flexible enough, it will not allow stretching in a single stage and it will be neces- sary to first implement an expander. Other complications could be due to the absence or maldevelopment of the shoulder girdle muscles, e.g. the pectoralis, latissimus dorsi, trapezius, or serratus anterior muscles [18, 19]. In case of an ipsilateral latissimus dorsi muscle defect, reconstruction of the chest wall and microsurgical or pedicled transfer of the rectus abdominis muscle (TRAM) might be the best choice for reconstruction. If the axillary vascular system is defective, the internal mammary vessels are used as recipients for free TRAM reconstruction.

In the literature, other techniques, e.g. laparoscopic reconstruction using the omentum flap technique or autologous fat injection, are described [12, 20].

In summary, reconstructive surgery depends on the severity of the malformation. A hypoplastic breast may be reconstructed with an implant (possibly expansion first). In case of maldeveloped muscles (e.g. the pectoralis muscle), an LD flap seems indicated. In case of additional thoracic malformations, more extensive, individual surgery is needed. Additionally, the position of the nipple-areola complex may need correction. For symmetry reasons, surgery to the contralateral breast can be considered. Reconstructive surgery in patients with Poland's syndrome is feasible and recommended for psychosocial reasons in these patients.

\section{Disclosure Statement}

All authors declare that they do not have any competing interests.

\section{References}

1 Poland A: Deficiency of the pectoralis muscles. Guy's Hosp Rep 1841;6:191.

2 Briner V, Thiel G: Hereditäres Poland-Syndrom mit Megacalicose der rechten Niere. Schweiz Med Wochenschr 1988;118:898-903.

3 Hedge HR, Leung AKC: Aplasia of pectoralis major muscle and renal anomalities. Am J Med Genet 1989;32:109-111.

4 Mingulla-Sola J: Poland's syndrome: a review of 38 cases. Am Esp Pedriatr 1998;48:143-147.

$\checkmark 5$ Tamiolakis D, Venizelios I, Antoniou C, Tsiminikakis N, Alifeieris E, Papadopoulos N: Breast cancer development in a female with Poland's syndrome. Onkologie 2004;27:569-571.

6 Ji J, Zhang S, Shao C, Xu M, Chen S, Lu C, Wang Z, Zhao Z, Fan X, Tu J: Poland's syndrome complicated with breast cancer: mammographic, ultrasonographic, and computed tomographic findings. Acta Radiol 2008;49:387-390.

7 Khandelwal A, O'Hea BJ, Garguilo G: Breast cancer in a patient with Poland's syndrome. Am Surg 2004;70:491-495.

8 Fijalkowska M, Antoszewski B: Surgical treatment of patients with Poland's syndrome - own experience. Pol Przegl Chir 2011;83:662-667.
9 Gascoigne AC, Malata CM: Pleural damage during capsulectomy and exchange of long-standing breast implants in Poland syndrome: A cautionary tale. Ann Plast Surg 2012;69:148-151.

10 Papadopulos NA, Eder M, Stergioula S, Teymouri HR, Mavroudis MC, Herschbach P, Henrich G, Papadopoulos ON, Biemer E, Kovacs L: Women's quality of life and surgical long-term outcome after breast reconstruction in Poland syndrome patients. J Womens Health (Larchmt) 2011;20:749-756.

11 Baratte A, Bodin F, Del Pin D, Wilk A, Bruant C: Poland's syndrome in women: Therapeutic indications according to the grade. Apropos of 11 cases and review of the literature. Ann Chir Plast Esthet 2011;56:33-42.

12 dos Santos Costa S, Blotta RM, Mariano MB, Meurer L, Edelweiss MI: Aesthetic improvements in Poland's syndrome treatment with omentum flap. Aesthetic Plast Surg 2010;34:634-639.

13 Fekih M, Mansouri-Hattab N, Bergaoui D, Chaieb A, Fikry T, Khairi H: Correction of breast Poland's anomalies. About eight cases and literature review. Ann Chir Plast Esthet 2010;55:211-218.

14 Borschel GH, Costantino DA, Cederna PS: Individualized implant-based reconstruction of Poland syndrome breast and soft tissue deformities. Ann Plast Surg 2007;59:507-514.

15 Freitas Rda S, o Tolazzi AR, Martins VD, Knop BA, Graf RM, Cruz GA: Poland's syndrome: different clinical presentations and surgical reconstructions in 18 cases. Aesthetic Plast Surg 2007:31:140-146.

16 Foucras L, Grolleau-Raoux JL, Chavoin JP: Poland's syndrome: clinic series and thoraco-mammary reconstruction. Report of 27 cases. Ann Chir Plast Esthet 2003;48:54-66.

17 Avci G, Misirlioglu A, Eker G, Aköz T: Mild degree of Poland's syndrome reconstruction with customized silicone prosthesis. Aesthetic Plast Surg 2003;27:112-115.

18 Rocha RP, Daher PF, Pinto EB, Saldana OR, de Sousa JE, Pacheco RB, Martins FB: Complication after breast implantation in Poland syndrome. Aesthet Surg J 2008;28:589-593.

19 Holm C, Mühlbauer C, Korinth C, Wörl HH: Breast cancer and reconstruction in a case of Amazon syndrome. Eur J Plast Surg 2001;24:144-148.

20 Pinsolle V, Chichery A, Grolleau JL, Chavoin JP: Autologous fat injection in Poland's syndrome. J Plast Reconstr Aesthet Surg 2008;61:784-791. 